Article

\title{
"It's Almost Impossible to Speak about It": Sexual Abuse, Forgiveness, and the Need for Restitution Rituals
}

\author{
Lisa Rudolfsson ${ }^{1, *}$ and Fredrik Portin ${ }^{2,3}$ (D) \\ 1 Psychology, Gothenburg Research Institute (GRI), University of Gothenburg, 40530 Gothenburg, Sweden \\ 2 Theology, Deptartment of Literature, History of Ideas, and Religion, University of Gothenburg, \\ 40530 Gothenburg, Sweden \\ 3 Deptartment of Theology, Åbo Akademi University, 20500 Turku, Finland; fredrik.portin@abo.fi \\ * Correspondence: lisa.rudolfsson@gri.gu.se; Tel.: +46-31-786-5876
}

Received: 21 November 2018; Accepted: 14 December 2018; Published: 18 December 2018

check for updates

\begin{abstract}
The focus of this research was on ways in which Christian congregations can address the concept of forgiveness when caring for victims of sexual abuse, and to make suggestions for a restitution mass as a possible way for congregations to work with these victims. Interviews with seven women and one man, who were victims of sexual abuse, were analyzed according to inductive thematic analysis. Our focus was on abuse that had occurred outside Church, i.e., not perpetrated by representatives for the Church. The informants described how attending services in Church could trigger their memories of sexual abuse, and they struggled to understand the concept of forgiveness; who they were to forgive and what made their forgiveness good enough. They expressed a need for the Church to offer them a safe space, rituals where their experiences would be acknowledged, and to meet with other victims of sexual abuse. We argue that representatives for the Church need to acquire knowledge about sexual abuse and its consequences before offering care. Further, the presence of victims of sexual abuse in a congregation demands that the congregation create appropriate conditions where the victim's needs and concerns are put into focus. Addressing forgiveness and offering rituals must be done in such a way that it does not consolidate the victim's feelings of exclusion, guilt, and shame.
\end{abstract}

Keywords: church; congregational care; Christian worship services; forgiveness; interview study; restitution ritual; sexual abuse; victims

\section{Introduction}

In Sweden, approximately 7 to 10 percent of the women and 1 to 3 percent of the men have been subjected to sexual abuse before the age of 16 (Brottsförebyggande Rådet 2008). In addition, studies show that one in every three women (34 percent) in Sweden have been subjected to sexual violence after the age of 15 (Brottsförebyggande Rådet 2011). Worldwide, a review of 55 studies from 24 different countries showed the prevalence of child sexual abuse to range from 8 to 31 percent for girls and 3 to 17 percent for boys (Barth et al. 2013).

Trauma reactions such as depression, anxiety, and post-traumatic stress disorder (PTSD) have been noted to be prevalent among those who have been sexually abused (Wilson and Miller 2016). Self-blame, feelings of loneliness, suicidal thoughts, and guilt are other negative consequences (Glenn and Byers 2009; Wilson and Miller 2016). Furthermore, shame has been emphasized as a central emotional consequence for individuals who have been sexually abused (Fiering et al. 2002; Fiering and Taska 2005). As the effects of sexual abuse are becoming more well known, so is awareness of 
the potential consequences of sexual abuse on the victim's faith (Farrell 2009). In a previous study (Rudolfsson et al. 2012), a majority of the 421 responding clerics (72.9 percent) reported that they had met victims of sexual abuse in their clerical work. This result is consistent with another study (Rudolfsson and Tidefors 2009) in which 77 percent of the responding clerics had met victims of sexual abuse. These findings indicate that many victims of sexual abuse seek guidance and support from their congregations, when trying to learn to live with what has happened.

One dimension of working through an overwhelming trauma, such as sexual abuse, is to find a way in which the individual can make sense of what has happened and possibly find some kind of meaning in it (Harvey et al. 1990; Park 2013). To comprehend the world, people require a system of meaning that can help them to navigate and organize their perception of events and offer a sense of purpose and direction in life (Park et al. 2013). Religion is one such way in which people can deal with existential and meaning-related needs (Park 2013). Previous research has focused on the relation between religiousness and mental health (Ano and Vasconcelles 2005; Pargament and Lomax 2013). Within the field of religious coping (i.e., how religiousness is incorporated in the individuals' coping-process), religion is sometimes discussed as both a resource and as a burden. This means that positive forms of religious coping (e.g., seeking spiritual support and benevolent reappraisals of God's power) have been associated with greater psychological well-being, whereas negative forms of religious coping (e.g., interpersonal and spiritual discontent) have been associated with the individual reporting more psychological stress (Pargament et al. 2000).

Several studies indicate that having been sexually abused is negatively associated with religious involvement, such as participation in church activities (Ben-Ezra et al. 2010; Hall 2008). As a person attempts to recover from a traumatic event, the domains of psychological trauma and spirituality seem to interact with each other (Smith 2004). Sexually abused individuals often display a great complex of trust problems (Herman 1992). If the victim is a member of a religious congregation, there is a risk that the lack of trust may be generalized to the ministry, to the congregation, and to God (Moran 1994). Traumatic experiences can disrupt people's sense of meaning and purpose in life (Smith 2004), leading to struggles to understand the trauma from a spiritual point of view (Jordan 1995). Among the struggle for Christian believers to understand the trauma from a spiritual point of view is the need to understand the concept of forgiveness.

Since its inception, Christian theology has emphasized the need for forgiveness as a way of restoring the relationship between fellow human beings. Accordingly, for Christians, forgiveness becomes an ethical imperative to strive for a form of forgiveness similar to that exemplified by Jesus in his life; an unconditional, unilateral, and never-ending forgiveness. Therefore, for some Christians, an inability to forgive can be perceived as a character flaw, which in turn makes feelings of guilt and shame understandable within a Christian context in light of this inability (Bash 2007; Zahnd 2010).

However, Christian theologians are, generally speaking, sensitive to the fact that there are crimes that are more or less impossible to forgive. As theologian Anthony Bash writes, some crimes challenge "beliefs that shape identity, sense of self-worth, confidence in the rules of justice, and the goodness of people" (Bash 2007, p. 11). Therefore, it becomes impossible to forgive the crime without also confronting and restructuring the victims' underlying beliefs. The possibility of fulfilling such a task will accordingly be dependent on the crime and the damage it has caused the victim. Thus, the greater the crime, the lesser the possibility for forgiveness (Forster 2017; Flanigan 1998).

Although it is possible to discuss whether forgiveness is always an absolute impossibility (Govier 1999), it is undeniably important that Christian congregations need to be careful that they do not convey a theology of forgiveness that could, in the theologian Dietrich Bonhoeffer's words, be described as "cheap". Forgiveness should not be presented as easy and as an ethical demand placed on the victim (Bonhoeffer 1995, pp. 43-56). Being a victim of sexual abuse challenges the possibility for an easy, or cheap, forgiveness. Cheap forgiveness, by more or less forcing the victim into a form of forgiveness that they do not need or are not capable of, threatens to trigger memories of the abuse and feelings of guilt and shame. As we will argue, the presence of victims of sexual abuse in a congregation 
therefore demands that the congregation create the appropriate conditions where the victim's needs and concerns are put into focus.

Out of our previous research on sexual abuse, faith, and Christian worship services, an interest arose to gain a deeper understanding of sexual abuse victims' descriptions of forgiveness and their expressed wishes for what the congregation would offer them. Clergy members have been much studied as perpetrators of sexual abuse, but far less so as resources for victims (Rudolfsson 2015). In this study, the focus is on sexual abuse that occur outside the Church (i.e., not perpetrated by a representative for the Church) and, hence, on representatives for the Church as resources for such victims.

The aim of this study was to formulate ways in which Christian congregations can address the concept of forgiveness when caring for victims of sexual abuse, and further, to make suggestions for a restitution mass as a possible way for congregations to work with these victims. To ensure that the suggestions made were in accordance with victims' own experiences and wishes, an analysis of interviews with Christian believers, who were victims of sexual abuse, was conducted.

\section{Materials and Methods}

\subsection{Informants}

Seven women and one man, aged from just over 20 to 70 years, participated in the study. All informants had been abused in the past, and to our knowledge no one was suffering ongoing sexual abuse at the time of the interview. Two had been raped as teenagers and six had been sexually abused as young children. Four of the informants were victims of incest; three were abused by their biological father or a close male relative and one by her biological mother. One informant was abused by an adoptive father and one by a nanny. Five informants were abused over a long period during their childhood, while the two who were raped as teens and the one abused by a nanny during childhood suffered occasional abuse. One informant, a victim of incest as a child, was also raped by a non-relative as a young adult. Four of the informants belonged to the Church of Sweden and four to the Swedish Free Church Movement.

\subsection{Procedure}

The informants were recruited through an advertisement posted on a national website for a Swedish organization offering support and help for victims of sexual abuse (www.hopp.org) and on billboards in different Churches in Sweden. The advertisement explained that participation was voluntary and anonymous and that informants had to be 18 years or older. Six informants responded to the advertisement on the website, one to the notice posted in a Church, and one after receiving information about the project through a pastoral caregiver. This study was approved by the regional ethical review board in Gothenburg, Sweden.

\subsection{Interview}

The interviews were semi-structured, and informants were allowed to decide for themselves what they wanted to share. The interview guide covered four main areas: (1) if, and how, the informants' relation to God had been affected by being a victim of sexual abuse; (2) if, and how, the informants' relation to other congregants had been affected by being a victim of sexual abuse; (3) how the informants related to certain Christian themes and concepts, such as forgiveness; and (4) informants' experiences of pastoral care and of help outside the Church. This article offers findings about the informants view of forgiveness, and about the informants' described wishes for what their Church would offer them. The informants' relation to God and to their congregation, their experiences of pastoral care, and of help outside the Church has been published in other papers (Rudolfsson and Tidefors 2014, 2015). 
The interviews were conducted during 2012-2013. The informants were given opportunities to present new angles and themes during the interviews, and at the end of the interviews all were asked whether there was anything else that they wanted to share. Time was allowed for informants to talk about their experience of participating and questions about how they thought they might feel later were asked. The informants were urged to make contact afterwards if they had any further questions or if they wanted to elaborate or clarify some of their thoughts. No compensation was offered for participation. The interviews took approximately $1.5 \mathrm{~h}$ each. Five were conducted at the Department of Psychology, Gothenburg, two at conference locales close to where the informants lived, and one at the home of an informant. All interviews were audio recorded and transcribed verbatim by the first author.

\subsection{Analysis}

The transcripts were analyzed according to inductive thematic analysis, which can be described as data driven or bottom up (Braun and Clarke 2006). As the focus for this study was on descriptions relating to forgiveness and what informants wished for from their Churches, only these statements were analyzed.

To get some context, the transcripts were first read and re-read as a whole by the first author. The dataset relating to descriptions of forgiveness and what the informants wished for from their Churches was then coded by the first author, who made no attempt to fit data into a pre-existing framework. Ideas that arose for possible structures for the data were noted. These ideas were then reviewed and new ideas were used in re-coding. Codes were first organized into seven themes: What is forgiveness; for whom is forgiveness; how is forgiveness done; a too "polished" Church; a wish for confirmation from the Church; a wish to meet others with my experiences; a wish for rituals. The coded data extracts were reviewed to investigate whether the themes captured and fit the dataset. The codes were then reorganized under two main themes found to capture the material: (1) a need to understand; (2) a need to feel included. Subthemes were created to structure the material and all data extracts were reviewed to find quotations that best captured the essence of each theme and subtheme.

\section{Findings}

The following text presents the different aspects of the informants' descriptions of forgiveness and their expressed wishes for what they needed their church to offer them according to the themes and subthemes identified in the analysis. For main and subthemes, see Table 1. These themes are discussed and the informants' thoughts and experiences are highlighted. Quotations have been edited and abbreviated to facilitate the reading. Quotes are presented without information about the informants to protect their confidentiality.

Table 1. Main themes and subthemes.

\begin{tabular}{cl}
\hline \multicolumn{1}{c}{ Main Theme } & \multicolumn{1}{c}{ Subtheme } \\
\hline A need to understand & $\begin{array}{l}\text { Who am I to forgive? } \\
\text { What makes forgiveness good-enough? }\end{array}$ \\
\hline A need to feel included & $\begin{array}{l}\text { I need to be acknowledged } \\
\text { I need a safe space }\end{array}$ \\
\hline
\end{tabular}

\subsection{A Need to Understand}

The informants spoke of their struggles with existential questions such as good and evil, and about how their faith had changed as a consequence of being a victim of sexual abuse. The informants also described their struggle to understand whom to forgive: themselves, their perpetrator, or God. They described a need to find their own way of forgiving, described as letting go of feelings of anger and revenge, and coming to terms with the fact God might forgive their perpetrator. 


\subsubsection{Who Am I to Forgive?}

The informants described how being a victim of sexual abuse had made them question much of what they had been taught about existential questions, such as the meaning of life and faith in God. Many informants also described questions about the balance between good and evil in the world and within humans. All informants described how acknowledging the feelings connected to the abuse and the struggles to understand what they had been through led to a transformed faith. When talking about forgiveness, many informants struggled to understand whom they needed to forgive. Mainly those informants who were abused by someone they loved and trusted during their childhood were sometimes still occupied with self-blame.

"I still feel like I am partly to blame. That is, I think that ... yes, I think that ... that is how I feel."

Some informants related their self-blame to the blurred boundaries between good evil as well as to their feelings of shame for not being able to stop the abuse. The need to forgive oneself for what had happened was sometimes described as harder than to forgive the perpetrator and other people who had not intervened to stop the abuse.

"When it comes to forgiving my [male relative and perpetrator] or other people around me

... sure, that is hard as well, but the hardest thing is to forgive yourself ..."

The informants described how being able to forgive their perpetrator was sometimes hindered by the perpetrator denying what had happened. A shared understanding of reality, and the perpetrator acknowledging guilt was described as a prerequisite for eventually being able to forgive. Some informants, who had been abused by a parent, spoke about how the concept of forgiveness didn't apply to them. They described how being a child abused by the one they depended on and trusted was an act where forgiveness had lost its meaning.

"Forgiveness postulates some kind of ... equality; that you are two people at the same level. Then you can say "okay I forgive you". However, when it comes to a parent abusing their own child, I mean the child is totally dependent on the parent to even exist ... as an individual. Well, forgiveness kind of loses its ... meaning in that context I think."

Although the informants spoke about a longing for God, many also described feelings of being angry at God for allowing them to be born into a situation where they were abused. The informants described feelings of being abandoned and betrayed by God for not stopping the abuse. When talking about these feelings of abandonment and anger, the informants also spoke about a need to forgive God. For some, forgiving God seemed to be at the core of their pain.

"If I can forgive God ... That is, ooh I feel like, it's like (crying). You know, I haven't worked that through yet. Since it affects me this much, that's how I feel."

\subsubsection{What Makes Forgiveness Good-Enough?}

When talking about forgiveness, a discrepancy emerged between what was perceived as the Church's view of forgiveness and the informants' own view. The informants described a demand to "forgive and move on", which was incompatible with their incapacity to surrender and move on from the abuse they had been subjected to. The informants spoke about how, in Church, forgiveness was not handled as the complex process they perceived it to be. Some seemed to be provoked by how forgiveness could make them feel, as if they should just accept the abuse they had suffered; that talk about forgiveness in Church was like saying that the abuse was okay. This view of forgiveness was described as making the informants feel silenced, and as making it harder for them to work through their experiences. 
"The way that forgiveness is talked about can lead to silencing and to making excuses, oh yes! Definitely. It's as if they have an idea that, well "you just have to forgive and everything will be fine" ... But really, it's a process ... and ... you might need to go through that process, even if it turns out that you cannot forgive."

Some informants spoke about how the concept of forgiveness had been used so often, and in such ways that it had lost its meaning. The perceived lack of understanding about how difficult it could be for someone who was a victim of sexual abuse to forgive was described as hurtful. Sometimes such feelings also led to feeling excluded from taking part in congregational activities. A wish to focus on forgiveness as healing, instead of as confession of sins and absolution was described.

"Well, instead of this confession of sins and receiving forgiveness, it's the other perspective that I need. That I have been ... that someone else has hurt me and I need ... to heal, not to forgive. Yes, I wish there was more room for that [in Church]."

The informants spoke of a need to heal, in the sense of learning to live with what had happened to them. For some, forgiveness was the same as finding solace in reconciling with the hurt they had been through. For others, the Christian virtue of forgiveness had become a burden; they felt forced to do something they did not know how to.

"At these times, it has felt like a burden ... and forgiveness is supposed to be something beautiful but really, to me it isn't. It is charged with so many other things ... "

All of the informants spoke of an inner need to forgive, however they all stressed that they had to be allowed to take their time in reaching some kind of forgiveness; not being rushed or pressured. Often, the informants spoke of forgiveness as getting rid of feelings of hatred, anger, and revenge. Reaching their own way of forgiving was often described as being able to "let go", not feeling occupied by negative feelings towards the perpetrator.

"When it comes to my [male biological relative and perpetrator], I'd rather say that I have forgiven him in the way that I can. And to me, that means to let go ... actually, forgiveness is to let go."

Although some informants spoke about having reached some kind of forgiveness, for others, being told that they did not need to forgive had been most helpful. One informant described how she had felt occupied with the thought of her going to hell if she wasn't able to forgive her perpetrator. Being assured by a pastoral caregiver that she did not have to forgive was described as comforting. Some informants also described comfort in the thought of God's final judgement. However, some informants also described it as a struggle to come to terms with the belief that maybe God would one day forgive their perpetrator.

“Sometimes I have thought that well, God might be able to forgive, but ... I can't and I don't have to. And after all, I think it's quite amazing that I have reached that point where I can feel it's okay if God forgives him."

\subsection{A Need to Feel Included}

The informants described feeling that the Church maintained a facade, all good and "polished". They described how sexual abuse was not spoken about, nor were the consequences of being a victim of sexual abuse. A need for validation and acknowledgement of their experiences from the Church was described, as well as a need for a safe place within the Church. Consequently, the informants highlighted the need for restitution rituals, where their pain would be acknowledged and where they could meet with other victims of sexual abuse. 


\subsubsection{Need to Be Acknowledged}

The informants described how a lack of understanding for what they had been through sometimes made them feel different and excluded from Church. Some were disappointed in how their congregations had handled their disclosure; for those informants, an anger towards the Church and the people associated with it became apparent. A perception that other congregants did not understand what it was like to be a victim of sexual abuse could lead to feelings of things being unfair.

"You see all these people who are successful, or at least you think that they have these successful lives. They make good money, they have their careers and they can manage to interact with others socially. And you can't help but to think it's bloody unfair."

The informants talked about the Church as holding up a facade of all Christians being happy and of the congregation as an ideal world. The informants described the Church as a place where people did not have the courage to speak about sexual abuse and its consequences, making the informants feel excluded and like there was no room for them in Church.

"Well, I have never heard anyone use the words sexual abuse in Church services, or that is, even if we know how common it is for people to be victims of sexual abuse ... they might have said "being taken advantage of". In some ways, it makes you feel like you don't exist."

Many informants spoke about a need for the Church to acknowledge their experiences as abuse. For some, this was described as a prerequisite for learning how to live with having been a victim of sexual abuse. At the same time, the informants expressed a fear that if they disclosed the abuse in Church they would be met with disbelief, and they gave examples of such experiences. When talking about these negative experiences, the informants stressed the need for the Church to be more knowledgeable about sexual abuse and its consequences. Without this knowledge, the Church became a place where the informants did not feel safe and sometimes made them distance themselves from taking part in for example services.

"I have ... a need to go to Church and I feel like ... sometimes it's calming to be there but (sigh) the services sometimes, they don't apply to me, there's so much ... there's no awareness about these things, no..."

Some informants described a feeling that they needed to fend for themselves when taking part in congregational activities. When not feeling validated, some informants could feel like they were abused once again.

"I have met many people in Church who go "there's a meaning to everything", but ... if you have been through what I have been, well, it has only meant hurt ... they don't know what I have been through, but still, I have questioned things, the meaning of, because to me there is no meaning to some things. Being told that everything has a meaning, that the abuse I have suffered has a meaning to it; it has felt like being abused once again. There are so many concepts used in Church that trigger the pain."

\subsubsection{Need a Safe Space}

When talking about their wishes for what the Church would offer them, the informants seemed to have a need to convince themselves that there must be others around them who shared their experience of what it was like to be a victim of sexual abuse. In these descriptions, the informants expressed a wish that the Church would address the congregants' experiences and pain; allowing more than just themselves to feel acknowledged.

"Well I mean, it cannot be, I know I'm not the only one ... I mean, there have to be many people who have been through hurtful ... experiences and so on, where those other perspectives would be needed." 
Some informants described having taken part in support groups for victims of sexual abuse. Meeting with others who had also been abused was described as comforting, and as normalizing their own reactions; making them feel less "crazy".

"It felt great to get to meet with others and it made me feel like I wasn't as crazy as I thought."

A need for more comforting stories was described. Many talked about how they found comfort in thinking of Jesus as someone who knew what it was like to suffer and who shared their pain. In relation to this, some informants spoke about a need for restitution masses where their experiences of being a victim of sexual abuse would be acknowledged.

"They had arranged for some special services, where there would be more room for ... well I'm not quite sure about the set-up. Because unfortunately, there wasn't any ... time and so ... I didn't get to go. But I remember feeling curious and feeling like ... that would have been a good thing for me."

However, the informants also spoke about how hard it was to find such masses.

"There wasn't ... no one would offer that ... I would have liked that. I would have come to that. That could have made me attend Church again."

One of the informants had experience of being in a Church in Norway, another Scandinavian country. There she had attended a restitution mass, where pillows and blankets had been placed at the altar; allowing the participants to sit in a ring. A rose had been passed around, said to symbolize one's wounds and pain, and the participants had each pulled a leaf from the rose before passing it on. This experience was described as powerful and comforting.

"I think the set-up is important, this non-authoritarian ... passing [the rose] around, it felt devotional because when you ... got it, when you tore a leaf off you were alone with your pain, but in the process of receiving it and passing it along you also shared your pain with the others."

\section{Discussion}

Several researchers have pointed to the role that spirituality may play for some adult survivors of childhood sexual abuse when learning to live with their experiences (Farrell 2009; Gall 2006; Lemoncelli and Carey 1996; Rudolfsson 2015). For survivors who feel that spirituality is relevant to their lives, negative forms of religious coping, such as disappointment or anger with God, may serve as signs of distress in their coping with current stress. In addition, positive forms of religious coping, such as seeking spiritual support from others or a loving God, may serve as supplementary resources for victims' coping with stress (Gall 2006). However, studies have also shown that the impact that sexual abuse can have on an individuals' faith is complex (Ben-Ezra et al. 2010), and further that an emphasis on forgiveness, may increase the victims' feelings of shame and guilt (Ganje-Fling and McCarthy 1996).

In this discussion, the findings will be discussed from a psychological perspective, where belongingness, the need for a safe space, and the risk of secondary victimization will be addressed. Thereafter, the findings will be addressed from a theological perspective, where the importance of Christian worship services will be highlighted. As a comparison, the Rainbow mass (i.e., a worship service around the concerns of HBTQ persons) will be described, after which suggestions for how to conduct a restitution mass for victims of sexual abuse will be given. Lastly, limitations of the study will be presented.

\subsection{Belongingness and the Need for a Safe Space}

Like all believers, the informants in this study listened to the words spoken in Church through a personal filter. This made the informants understand what was said through the experience of having 
been sexually abused. The informants described how attending services in Church could trigger their memories of sexual abuse, and they struggled to understand the concept of forgiveness: who they were to forgive and what made their forgiveness good-enough. These struggles were also described as making them feel different from the other congregants, and they expressed a need for the Church to offer them a safe space and rituals where their experiences would be acknowledged and where they could meet with others who shared their experience of being a victim of sexual abuse.

The need to belong has been conceptualized as a basic human motivation, a pervasive drive to form and maintain lasting, positive, and significant interpersonal relationships (Baumeister 1991; Baumeister and Leary 1995). In this study, informants described that being a victim of sexual abuse made them feel different and sometimes excluded from the congregation. They wished for a Church that would validate their experiences and a need for rituals that could acknowledge their hurt. Flynn (2008) found in studies of Christian women who had been sexually abused, that the impact of the abuse was less stigmatizing when the faith communities validated the abuse experiences and created psychological confirmation by showing belief and support for the women. In this study, when lacking this validation, one informant described it as making her feel like she didn't exist, indicating the psychological power of belongingness.

The informants in this study described forgiveness as a process and as letting go of anger and thoughts of revenge. Some researchers have discussed the helpfulness of forgiveness when working through, for example, thoughts of revenge (McCullough and Witvliet 2002); others emphasize the risk of forgiveness being apprehended as a demand and, thus, becoming another burden for the victim to bear (Ganje-Fling and McCarthy 1996; Fortune 1988; Redmond 1989). There is a risk that an emphasis on forgiveness may obstruct the victims' needs to articulate feelings of anger and betrayal. On one hand, the informants in this study expressed the feeling that forgiveness could become a burden to them, and further, that talk about forgiveness could make them feel like the abuse they had suffered was in some ways excused. One of the participants even said that it's almost impossible to speak about forgiveness in relation to a child being sexually abused. On the other hand, the informants also expressed a need to work with forgiveness and to come to their own understanding about forgiveness, and a need for rituals where their wounds could be acknowledged. Representatives of the Church, therefore, have an important role to fill when addressing forgiveness, in an unburdening way. However, the ways to address forgiveness when caring for victims of sexual abuse need to be handled with care. Previous research shows that there is a risk that an insensitive way of addressing forgiveness might make victims fear God's punishment (Ganje-Fling and McCarthy 1996) or feel unworthy of God's grace if they are unable to forgive (Kleiven 2010). This was also described by the informants in this study.

People who have been sexually abused as children often retain experiences of betrayal by caregivers, broken trust, misuse of power, and boundary violations (Herman 1992; Freyd 2008). Abused individuals tend to develop negative models about self and others that may lead to relational difficulties and difficulties regulating emotions (Kaplan 2006; Romans et al. 1995). (Kaplan 2006; Böhm and Kaplan 2010) stresses the importance of creating a safe psychological space for the traumatized individual where threatening and intrusive thoughts can be kept at a distance. In this safe space, the traumatized individual will have a better chance of regulating their emotions and upholding significant interpersonal relations. The informants in this study expressed a need for such a safe space within their Church, where they could also meet with other victims of sexual abuse. Offering restitution rituals could be one way for the Church to create such a safe space and enable victims to meet with others who share their experiences.

\subsection{The Risk of Secondary Victimization}

Previous research indicates that caring for victims of sexual abuse is associated with discomfort and insecurity (Goldblatt 2009), and many representatives of the Church feel unprepared and report 
a lack of knowledge about how to care for victims of sexual abuse within their congregations (Bruns et al. 2005; Rudolfsson and Tidefors 2009; Rudolfsson and Tidefors 2013).

In this study, the informants described that if representatives of the Church did not have knowledge about sexual abuse, the Church became a place where they did not feel safe. Not feeling safe had also forced some of them to distance themselves from taking part in, for example, services in Church. As several trauma reactions, including PTSD, have been noted to be prevalent among those who have been sexually abused (Wilson and Miller 2016), it could be important for clergy to be able to recognize such reactions and the victims' need for psychiatric care (Milstein et al. 2017; Noort et al. 2012). Representatives of the Church should not treat psychiatric symptoms, and need to be aware when a victim's reactions exceed their competence.

Several studies show that victims of sexual abuse are often afraid to disclose their experiences out of fear of negative reactions from others (Fiering et al. 2002). Previous research has also shown that victims often blame themselves for the abuse and that many feel ashamed of what they have been through (Fiering and Taska 2005). In this study, the informants described this as a struggle to understand how to forgive oneself for not being able to stop the abuse. The therapeutic effect of disclosing having been a victim of sexual abuse seems to depend on whether the victim feels that the one listening is empathetic and supportive. Some studies have even shown that if the one listening does not show empathy and support, the victims' psychological suffering might increase (Patterson 2010).

In the literature, this is referred to as secondary victimization and describes the risk that disclosure can increase and exacerbate the traumatic experience of being sexually abused (Campbell and Raja 1999; Patterson 2010). Examples of secondary victimization are if the victim feels that their story is met with disbelief, or if the one listening is cold and distant (Campbell 2005; Patterson 2010). Being met with these attitudes can increase the victims' feelings of shame and anger and further increase the risk of the victim blaming themselves for what has happened (Maddox et al. 2011). In this study, the informants described that when their experiences were not validated, it was like being abused once again. Consequently, if a representative of a Christian congregation wants to offer care to victims of sexual abuse, knowledge about sexual abuse and its consequences need to be acquired and the risk of secondary victimization needs to be taken into consideration.

\subsection{The Importance of Christian Worship: The Rainbow Mass as an Illustrative Example}

Besides the importance of creating a safe psychological space for the traumatized individual where threatening and intrusive thoughts can be kept at a distance, the need to develop Christian worship services as a safe space for victims of sexual abuse is also theologically motivated. A common feature of most Christian denominations, including the denominations that the informants in this study are or had been part of, is that they center their practices and the formation of community around the worship service. Most Christian theologians argue that by taking part in the Eucharist, the Christian becomes part of the body of Christ. "This is my body," as Jesus emphasizes during the last meal (Luke 22: 19-20). Paul further emphasizes that this body is an image of the Christian Church, thus, referring to the community of believers (1 Corinthians 12: 12-14) (Dix 2005, pp. 1-2).

Although the worship service, generally speaking, has this role in Christian congregations, the informants in this study described how the services need to be revised to better consider the needs of the victims of sexual abuse. If the victim is forced to attend a worship service without having adjusted it to guarantee the victim's safety, the congregation will only reinforce the victim's perception that the congregation is not attentive to her or his needs. Instead, the congregation might be perceived as a place for tired clichés of forgiveness and suffering. The language used, the narratives reproduced, and the rituals practiced must therefore be revised so that they do not consolidate the victim's feeling of exclusion, guilt, and shame.

In order to succeed with such a task, an appropriate strategy could be to develop a worship service that is attentive to the needs and the concerns of victims of sexual abuse; a restitution mass. Worship services cantered on a particular topic or specific group of people are relatively common in 
Scandinavian countries (Edgardh 2016). An illustrative example of the value of such worship services, in the work of those who have become victims of injustice, can be seen in the work of HBTQ persons in Helsinki, Finland.

In a similar manner as the informants in this study expressed a distance to the congregation, HBTQ persons constitute a group of people who have a legitimate experience of exclusion in relation to the Church community. As representatives of the Church often has had (and still has) a condescending attitude towards HBTQ persons (priests, among others, have argued that HBTQ persons are morally bankrupt and live contrary to God's creation by not conforming to the natural order), many HBTQ persons have felt that they are not welcomed within the Christian community (Mathewes 2010, pp. 97-101). This was a wrong-doing that one congregation in particular, Johannes congregation in Helsinki, wanted to remedy by arranging a so-called "Rainbow mass".

The Rainbow mass is a worship service that highlights the need for, and value of, diversity within the Church, specifically by centering the worship service on the concerns of HBTQ persons. In order to arrange a worship service that is attuned to these needs, they, among other things, invited HBTQ persons to be involved in the planning and execution of the worship service. The sermons and prayers also highlight themes that are in tune with these concerns, for example themes on diversity and sexuality. Furthermore, the Church building is decorated with rainbow flags. A general purpose of these worship services is, thus, to offer a Christian place of worship where the concerns of HBTQ persons are taken seriously, and to show that they have a natural and valued place within the Church community. One of the pastors responsible for the Rainbow mass in Helsinki, Tomas Ray, has therefore described it as "the Church's reconciliation with sexual minorities, a kind of service for atonement" (Ray 2013, p. 93).

The purpose is, thus, to create a space within the Church where the marginalization of HBTQ persons can be challenged and where the Church can atone for past mistakes. Worthy of attention is the emphasis on the Church's needs for atonement. In order for the relationship between HBTQ persons and the Church to be re-established, responsibility is put on the Church, instead of putting the responsibility on HBTQ persons (e.g., by emphasizing that they must adapt to a heteronormative ideal in order to become an appreciated and valued part of the Christian community). Consequently, the Rainbow mass is a practice used to enable reconciliation.

The Rainbow mass also plays an important mediating role between HBTQ persons and the rest of the congregation, by offering everyone a space for reconciliation. Because this site is arranged around the needs and concerns of HBTQ persons, it can serve as a safe space where the victim of exclusion is put into focus. Such a practice can further enable HBTQ persons to find a place within the traditional worship service as well. The proof that this happens can only be anecdotal, but Ray points out that, thanks to the Rainbow mass, some HBTQ persons have found a place within the congregation's traditional worship service (Ray 2013).

The experience of the work with the Rainbow mass shows, first of all, how a congregation can effectively put the victim's needs and concerns into focus. The congregation does not demand anything from the victim. Instead, the goal is to create a safe space for HBTQ persons where exclusions in the past are confronted. Second, the Rainbow mass works as such a safe space because the language used, the narratives reproduced, and the rituals practiced are designed to avoid former judgmental attitude towards HBTQ persons.

If these insights are related to victims of sexual abuse and the possibility of them participating in congregational practices, the crucial question does not become what the victim must do to find a place within the community. Instead, the crucial question becomes how the congregation can create practices that take the victim's needs and concerns into account. Thus, how is it possible to create a worship service that offers victims of sexual abuse a safe space where they can both rest from the negative feelings that are associated with the abuse, and further, facilitate the victim reaching a forgiveness that is helpful to them and according to their own ability. 


\subsection{Restitution Mass for Victims of Sexual Abuse}

The aim of this study was to formulate ways in which Christian congregations can address the concept of forgiveness when caring for victims of sexual abuse, and further, to make suggestions for a restitution mass as a possible way for congregations to work with these victims. In order for a congregation to achieve such goals, constructive-practical frameworks for developing the work with victims of sexual abuse within congregations need to be formulated.

Based on the descriptions by the informants in this study, these frameworks must meet two criteria. First, the focus of the work must be the victim's needs and concerns. This entails, among other things, that the congregation need to be aware of the limits of fully understanding the victim's experiences, thus, also her or his needs. Therefore, the congregation need to be receptive to what the victim wants, and avoid delivering ready-made solutions to their situation. Second, in line with Kaplan (2006), we argue that the practical implications of this work must be the formation of safe spaces where the victim's situation is recognized, but where feelings of shame and guilt are avoided. In particular, the work must be characterized by a humble attitude, avoiding finding simple solutions to the victim's situation; as one informant expressed, a "forgive and move on" mentality should be avoided. This means that a cheap form of forgiveness (Bonhoeffer 1995) needs to be avoided. The goal is instead to create a space for the victim, where the practical and narrative conditions allow the victim to find rest from the negative feelings associated with the abuse. Such a safe space will also offer the victim a better chance to find rest and peace enough to, possibly, forgive in the way they find most comforting.

We argue that a restitution mass is one way to be attentive to these insights, as it both creates a safe space for victims of sexual abuse, and makes it possible for the congregation to work with these victims.

As already stressed, in light of the trauma suffered by victims of sexual abuse, the congregation needs to be vigilant not to trigger traumatic memories of the abuse and the negative feelings associated with them, in particular the feelings of shame and guilt, through certain vernacular or ritual features. This entails, among other things, that the choice of Bible texts, prayers, confessions, and hymns must be adapted according to the victim's needs and concerns. This requires great humility from the congregation and a willingness to listen. A lesson from the work with the Rainbow mass that can be made is to allow the victims themselves to plan and execute a worship service, if they should desire to do so. Allowing victims to participate in the planning, could also make them feel involved in the formation of the space that is created, as well as give them a greater opportunity to communicate their needs and concerns (Modeus 2005).

An attempt to create a worship service that can serve as safe space for victims of sexual abuse has been created by The Church Resource Center Foundation against violence and sexual abuse (Stiftelsen Kirkelig Resurssenter mot vold og seksuelle overgrep), a part of the Church of Norway. The foundation's purpose is to accomplish the Church's diaconal mission in the face of people exposed to violence and sexual abuse (Stiftelsen Kirkelig Resurssenter a. n.d.). In order to fulfil their purpose, they work towards the prevention of sexual abuse within the Church, help those exposed to sexual abuse, and train staff within the Church of Norway to become more competent in caring for victims of sexual abuse (Stiftelsen Kirkelig Resurssenter b. n.d.).

As part of their work, the foundation has developed a worship service that highlights and address sexual abuse. As presented above, one of the informants in this study describes an experience of participating in such a worship service.

Overall, the worship service that the foundation has developed does not differ significantly from the traditional worship service within the Church of Norway. What, on the other hand, makes it unique is that its goal is to focus on the needs and concerns of victims of sexual abuse. Consequently, they strive to create a narrative and practical foundation in the worship service, where the victim's feelings of guilt and shame are avoided. Among other things, this is done by emphasizing that the 
victim is more than the abuse they suffered, while at the same time confirming their value before God and other congregants.

This value is confirmed in the ritualistic expressions during the worship service. For instance, during the worship service the participants are asked to walk up to the baptismal font and retrieve a small gem. The baptismal font is filled with different colored beads, and they are said to serve as a symbolic reminder of their value: "[It] will remind you that you are valuable. You possess a dignity" (Stiftelsen Kirkelig Resurssenter c. n.d.). The participants are also allowed to take their gem home. Symbolically, it is significant that the beads are retrieved from the baptismal font. According to most Christian denominations' theology, baptism is a ritual where the baptized is incorporated into the Christian community, and where the baptized receives the grace of God (Inbody 2005). Retrieving a gem from the baptismal font, thus, has a relational significance in a double sense, as it both confirms the relationship with God and to the congregation.

The endeavor to give privilege to the needs and concerns of the victim appears in the reading of the creed that is read jointly during the worship service. Instead of using the Nicene or Apostolic creed, that is customary in the worship services of the Norwegian Church (The Church of Norway 2011), they have formulated their own creed. It reads:

I believe in a God who seeks out people.

I believe in a God who is able to see, hear and know.

I believe in Jesus who was subjected to abuse and betrayal.

I believe in Jesus who gives us part in his victory over evil and death.

I believe in the Holy Spirit who hopes for us when we cannot hope for ourselves.

I believe in the Holy Spirit that liberates us to act and to rest.

We believe that the Church wants to hear our voices.

We believe that the Church will fight against injustice.

(Stiftelsen Kirkelig Resurssenter d. n.d.)

Just as in the Nicene or Apostolic Creed, four general themes are highlighted: God the Father, the Son, the Holy Spirit, and the Church. However, in this creed the emphasis is on how these are linked to victims of sexual abuse. First, God is described as someone who takes the victim's needs and affairs seriously. The informants in this study described a longing for God while at the same time feeling angry and betrayed by Him for not stopping the abuse. In this creed, God is situated as someone seeking them out, possibly unburdening their struggles to reach Him. Jesus, in turn, is described as one who himself has been subjected to abuse, but that also was victorious over evil. The informants in this study described how they felt comfort in thinking of Jesus as someone who knew what it was like to suffer and who shared their pain. The Holy Spirit gives hope to the hopeless, as well as the desire to struggle, and further, the ability to rest. The Church, finally, is presented as a community willing to share the victim's suffering and to fight injustice. The creed is thus clearly formulated so that the victim's needs and concerns are made into the congregation's ultimate concern. The shift from "I believe" to "we believe" also highlights the belongingness possible in a Christian congregation, as well as emphasizing the Church's responsibility.

This creed is just one example of how it is possible to work with victims of sexual abuse within the framework of the worship service. As such, the practices highlighted above do not represent the only options for working ritualistically-symbolically with victims of sexual abuse. Local variations may, and should, occur. However, as an example, they demonstrate the need to formulate traditional texts and prayers, and to create new rites that contribute to the improvement of the victim's situation. In this way, focus can be the victim's needs and concerns, not the congregation's predetermined rituals and insufficient theologies on forgiveness.

Two aspects of this worship service are worth highlighting. First, as the service is developed from the needs and concerns of the victim, it allows for the formation of a safe space where the victim's situation is acknowledged, while avoiding feelings of shame and guilt. Second, the worship 
service offers a place where victims of sexual abuse can meet others with similar experiences. Thus, the experience conveyed is of not being the only one, which was also described by one of the informants in this study.

At this stage, we do not have enough empirical evidence to point out the results of such worship services. Further research is, therefore, needed. But as one of the informants who participated in the Norwegian worship service emphasized, it was a powerful and comforting experience. It is worth repeating the importance of the set-up as non-authoritarian, as it highlights that the worship service, instead of being a place that forces the congregant to accept a theological authority or a set of collective norms, focuses on the experience of being part of a larger community that does not require something that the victim of sexual abuse might neither be ready for, nor have the capacity for. To return to Bonhoeffer 1995 (1995), the experience of participating in a restitution mass, described by the informant in this study, was a space where forgiveness was not cheap. This is a forgiveness that does not require the victim to forget what happened to them; a "forgive and forget" mentality. Instead, the abuse was highlighted and confronted within a safe space. However, this must not be done in a way that puts all responsibility for the memories of the abuse on the victim. Instead, the victim must be allowed to (especially symbolically) share their pain, thus, allowing the congregation to bear some of the burden they usually have to bear alone. In this study, the informants described not feeling safe in the congregation and, although expressing a need to go to Church, some of them felt forced to distance themselves from taking part in, for example, worship services. When offering victims of sexual abuse a safe space within the Church and a restitution mass, the congregation fulfils a concrete Christian responsibility. Accordingly, we chose to end this discussion, by quoting Paul in his letter to the Galatians: "Carry each other's burdens, and in this way you will fulfil the law of Christ" (Galatians 6:2).

\subsection{Limitations}

The abuse that the informants in this study had suffered occurred outside the Church (i.e., it was not perpetrated by representatives for the Church). In recent years, the suffering and pain of those abused by clergy has received increased attention in research (Terry 2015). It is reasonable to assume that the suffering and pain of victims of abuse perpetrated by clergy raises even more challenging questions in regard to the congregation as a safe space. The results found in this study might, therefore, not be applicable to such abuse victims.

In this study, one informant had been raped just a few years prior to the interview, but most of the informants had been sexually abused many years ago—often decades prior. This means that they have had many years to process their experiences. The descriptions of forgiveness as well as the need for restitution rituals might therefore be different for someone who has just recently suffered sexual abuse.

Furthermore, the informants in this study had suffered different forms of sexual abuse: occasional or repeated, as children or as young adults, by a parental figure or by a non-relative. Previous research has pointed to the importance of differentiating between different forms of abuse in order to understand the consequences of sexual abuse (Chen et al. 2010). However, the focus of this research was to formulate ways in which Christian congregations can address the concept of forgiveness when caring for victims of sexual abuse, and further, to make suggestions for how a restitution ritual for victims of sexual abuse could be conducted.

The aim of this research, to make suggestions for a restitution mass, means that the material was analyzed from a perspective of the informants wishing to stay in their congregations. This means that another focus, and other researchers, might have found other meanings in what was said. However, these findings are one version of how to capture the informants' descriptions and experiences.

\section{Conclusions and Practical Implications}

- The suffering and pain of victims of abuse perpetrated by a representative for the Church raises even more challenging questions in regard to the congregation as a safe space. The informants in this study had all suffered abused that occurred outside the Church. The conclusions listed 
below should, therefore, not be applied to victims who has been abused by a representative for the Church. How the congregation could possibly function as a safe space for such victims, needs further investigation, beyond the scope of this study.

- Representatives for the Church should not treat psychiatric symptoms. They need to be aware when a victims' reactions exceed their competences and, in such cases, refer the victim to a clinical specialist. Furthermore, even when referrals do not need to be made, if a representative of a Christian congregation want to offer care to victims of sexual abuse, knowledge about sexual abuse and its consequences need to be acquired, including the risk of secondary victimization.

- Forgiveness can become a burden for someone who has suffered sexual abuse, and an insensitive way of addressing forgiveness can make victims feel like the abuse they have suffered is in some ways excused. However, victims of sexual abuse might also need to be allowed to work with forgiveness and to come to their own understanding about forgiveness. Therefore, representatives of the Church have an important role to fill when addressing forgiveness, in an unburdening way.

- When caring for victims of sexual abuse, the congregation needs to be vigilant not to trigger traumatic memories of the abuse and the negative feelings associated with them. The choice of Bible texts, prayers, confessions, and hymns must be adapted according to the victim's needs and concerns. The language used, the narratives reproduced, and the rituals practiced must be revised so that they do not consolidate the victim's feeling of exclusion, guilt, and shame.

- A safe psychological space, where threatening and intrusive thoughts can be kept at a distance, will give the traumatized individual a better chance to regulate their emotions and uphold significant interpersonal relations. A restitution mass is one way for the Church to create such a safe space, and further to enable victims to meet with others who share their experiences. The responsibility for the memories of the abuse should not be put on the victim alone. Instead, the victim needs to be allowed to share their pain, allowing the congregation to bear some of the burden they usually have to bear alone.

- The frameworks for a restitution mass should be developed from the needs and concerns of the victim, allowing for the formation of a safe space where the victim's situation is acknowledged, while avoiding feelings of shame and guilt. The set-up for a restitution mass should be non-authoritarian.

- Generally speaking, Christian theologians are sensitive to the fact that there are crimes that are more or less impossible to forgive. When addressing forgiveness, a "forgive and forget" mentality should be avoided; instead the focus should be to create a safe space where the victim is not required to forgive in a way that they might neither be ready for, nor have the capacity for. In particular, the work must be characterized by a humble attitude, avoiding finding simple solutions to the victim's situation.

- The goal of a restitution mass should be to create a safe space for the victim, where the practical and narrative conditions allow the victim to find rest from the negative feelings associated with the abuse. Such a safe space will offer the victim a better chance to, possibly, forgive in the way they find most comforting. Such a forgiveness could involve letting go (of feelings of anger and revenge), or coming to terms with the idea that God might forgive their perpetrator. It could also mean helping the victims to find comfort in being assured that they do not have to forgive.

Author Contributions: L.R. recruited the informants, conducted and transcribed the interviews, conducted the analysis and wrote the methods and material section as well as the findings section. L.R. also contributed the discussion of the results from a psychological perspective (sections belongingness and the need for a safe space; the risk of secondary victimization). F.P. thoroughly read the findings and contributed the discussion from a theological perspective (sections the importance of Christian worship: the rainbow mass as an illustrative example; restitution mass for victims of sexual abuse). Both authors co-authored the introduction as well as conclusions and practical implications.

Funding: This study was funded by the Swedish Research Council (344-2009-6599).

Acknowledgments: We wish to offer our warmest thank to the informants for sharing their stories with us. 
Conflicts of Interest: The authors declare no conflict of interest.

\section{References}

Ano, Gene G., and Erin B. Vasconcelles. 2005. Religious coping and psychological adjustment to stress: A meta-analysis. Journal of Clinical Psychology 61: 461-80. [CrossRef] [PubMed]

Barth, Jürgen, Lilian Bermetz, Eva Heim, Sven Trelle, and Thomai Tonia. 2013. The current prevalence of child sexual abuse worldwide: A systematic review and meta-analysis. International Journal of Public Health 58: 469-83. [CrossRef] [PubMed]

Bash, Anthony. 2007. Forgivness and Christian Ethics. Cambridge: Cambridge University Press.

Baumeister, Roy F. 1991. Meanings of Life. New York: Guilford Press.

Baumeister, Roy F., and Mark R. Leary. 1995. The need to belong: Desire for interpersonal attachments as a fundamental human motivation. Psychological Bulletin 117: 497-529. [CrossRef] [PubMed]

Ben-Ezra, Menachem, Yuval Palgi, Dina Sternberg, Dina Berkley, Hadar Eldar, Yael Glidai, Liron Moshe, and Amit Shrira. 2010. Losing my religion: A preliminary study of changes in belief pattern after sexual assault. Traumatology 16: 7-13. [CrossRef]

Böhm, Thomas, and Suzanne Kaplan. 2010. Hämnd eller upprättelse-hämndspiralens psykologi [Revenge: On the Dynamics of a Frightening Urge and Its Taming]. Stockholm: Natur och Kultur.

Bonhoeffer, Dietrich. 1995. The Cost of Discipleship. New York: Touchstone. First published 1965.

Braun, Virginia, and Victoria Clarke. 2006. Using thematic analysis in psychology. Qualitative Research in Psychology 33: 77-101. [CrossRef]

Brottsförebyggande Rådet [The Swedish National Council for Crime Prevention]. 2008. Våldtäkt mot personer 15 år och äldre: Utvecklingen under åren 1995-2006. Rapport 2008:13 [Rape against Persons 15 Years and Older: Crime Statistics during the Years 1995-2006, Report 2008:13]. Stockholm: Brottsförebyggande Rådet.

Brottsförebyggande Rådet [The Swedish National Counsil for Crime Prevention]. 2011. Polisanmälda våldtäkter mot barn. Brå rapport 2011:6 [Police-Reported Rapes of Children: An Update and Comparison of the Years 1995 and 2008, Report 2011:6]. Stockholm: Brottsförebyggande Rådet.

Bruns, Eric J., Carla Lewis, Linda M. Kinney, Leah Rosner, Mark D. Weist, and Joyce A. Dantzler. 2005. Clergy members as responders to victims of sexual abuse and assault. Journal of Religion and Spirituality in Social Work: Social Thought 24: 3-19. [CrossRef]

Campbell, Rebecca, and Sheela Raja. 1999. The secondary victimization of rape victims: Insights from mental health professionals who treat survivors of violence. Violence and Victims 14: 261-75. [CrossRef] [PubMed]

Campbell, Rebecca. 2005. What really happened? A validation study of rape survivors' help-seeking experiences with legal and medical systems. Violence and Victims 20: 55-68. [CrossRef] [PubMed]

Chen, Laura P., Hassan Murad, Molly L. Paras, Kristina M. Colbenson, Amelia L. Sattler, Erin N. Goransson, Mohamed B. Elamin, Richard J. Seime, Gen Shinozaki, Larry J. Prokop, and et al. 2010. Sexual abuse and lifetime diagnosis of psychiatric disorders: Systematic review and meta-analysis. Mayo Clinic Proceedings 85: 618-29. [CrossRef] [PubMed]

Dix, Dom Gregory. 2005. The Shape of the Liturgy. New York: Continuum. First published 1945.

Edgardh, Ninna. 2016. Nordiska perspektiv på gudstjänstreformer: Recensionartikel [Nordic perspectives on reforms of worship services: Review article]. Årsbok för svenskt gudstjänstliv, [Year Book for Swedish Worhip Services] 91: 171-81.

Farrell, Derek P. 2009. Sexual abuse perpetrated by Roman Catholic priests and religious. Mental Health. Religion and Culture 12: 39-53. [CrossRef]

Fiering, Candice, and Lynn S. Taska. 2005. The persistence of shame following sexual abuse: A longitudinal look at risk and recovery. Child Maltreatment 10: 337-49. [CrossRef] [PubMed]

Fiering, Candice, Lynn S. Taska, and Michael Lewis. 2002. Adjustment following sexual abuse discovery: The role of shame and attributional style. Developmental Psychology 38: 79-92. [CrossRef]

Flanigan, Beverly. 1998. Forgivers and the Unforgivable. In Exploring Forgiveness. Edited by Robert D. Enright and Joanna North. Madison: The University of Wisconsin Press.

Flynn, Kathryn A. 2008. In their own voices: Women who were sexually abused by members of the clergy. Journal of Child Sexual Abuse 17: 216-37. [CrossRef] [PubMed] 
Forster, Dion. 2017. The (Im)possibility of Forgiveness? An Empirical Intercultural Bible Reading of Matthew 18: 15-35. Stellenbosch: African Sun Media.

Fortune, Marie M. 1988. Forgiveness: The last step. In Abuse and Religion: When Praying Isn't Enough. Edited by Anne L. Horton and Judith A. Williamson. Toronto: Lexington Books, pp. 215-20.

Freyd, Jennifer J. 2008. Betrayal trauma. In Encyclopedia of Psychological Trauma. Edited by Gilbert Reyes, Jon D. Elhai and Julian D. Ford. New York: John Wiley and Sons, p. 76.

Gall, Terry Lynn. 2006. Spirituality and coping with life stress among adult survivors of childhood sexual abuse. Child Abuse and Neglect 30: 829-44. [CrossRef] [PubMed]

Ganje-Fling, Marilyn A., and Patricia McCarthy. 1996. Impact of childhood sexual abuse on client spiritual development: Counseling implications. Journal of Counseling and Development 74: 253-58. [CrossRef]

Glenn, Shannon A., and E. Sandra Byers. 2009. The roles of situational factors, attributions, and guilt in the well-being of women who have experienced sexual coercion. The Canadian Journal of Human Sexuality 18: 201-19.

Goldblatt, Hadass. 2009. Caring for abused women: Impact on nurses' professional and personal life experiences. Journal of Advanced Nursing 65: 1645-54. [CrossRef] [PubMed]

Govier, Trudy. 1999. Forgiveness and the Unforgivable. American Philosophical Quarterly 36: 59-75.

Hall, Kathryn. 2008. Childhood sexual abuse and adult sexual problems: A new view of assessment and treatment. Feminism and Psychology 18: 546-56. [CrossRef]

Harvey, John H., Terri L. Orbuch, and Ann L. Weber. 1990. A social psychological model of account-making in response to severe stress. Journal of Language and Social Psychology 9: 191-207. [CrossRef]

Herman, Judith L. 1992. Trauma and Recovery. New York: Basic Books.

Inbody, Tyron. 2005. The Faith of the Christian Church: An Introduction to Theology. Cambridge: William B. Eerdmans Publishing Company.

Jordan, Merle R. 1995. A spiritual perspective on trauma and treatment. NCP Clinical Quarterly 5: 9-10.

Kaplan, Suzanne. 2006. Children in genocide: Extreme traumatization and the 'affect propeller'. The International Journal of Psychoanalysis 87: 725-46. [CrossRef] [PubMed]

Kleiven, Tormod. 2010. Intimitetsgrenser og Tillitsmakt. Kirkesamfunns forståelse av og handlingsstrategier i møte med anklager om seksuelle krenkelser sett $i$ lys av et diakonifaglig perspektiv [Intimacy boundaries and the Power of Trust: The Understanding and Policies of Denominations Encountering Accusations of Sexual Misconduct Elucidated from a Diaconal Perspective]. Oslo: Diakonova.

Lemoncelli, John, and Andrew Carey. 1996. The psycho-spiritual dynamics of adult survivors of abuse. Counselling and Values 40: 175-84. [CrossRef]

Maddox, Lucy, Deborah Lee, and Chris Barker. 2011. Police empathy and victim PTSD as potential factors in rape case attrition. Journal of Police and Criminal Psychology 26: 112-17. [CrossRef]

Mathewes, Charles. 2010. Understanding Religious Ethics. Oxford: Blackwell Publishing.

McCullough, Michael E., and Charlotte Vanoyen Witvliet. 2002. The psychology of forgiveness. In Oxford Handbook of Positive Psychology. Edited by Charles R. Snyder and Shane J. Lopez. New York: Oxford University Press, pp. 446-55.

Milstein, Glen, Dennis Middel, and Adriana Espinosa. 2017. Consumers, clergy, and clinicians in collaboration: Ongoing implementation and evaluation of a mental wellness program. American Journal of Psychiatric Rehabilitation 20: 34-61. [CrossRef]

Modeus, Fredrik. 2005. Mod att vara kyrka: Om församlingsbygge och kyrkans identitet. [Courage to Be the Church: On the Development of Congregations and the Identity of the Church]. Stockholm: Verbum.

Moran, Patricia A. 1994. Children as victims of sexual abuse. In Slayer of the soul: Child Sexual Abuse and the Catholic Church. Edited by Stephen J. Rosetti. Mystic: Twenty-Third Publications, pp. 67-82.

Noort, Annemarie, Arjan Braam, Arthur van Gool, and Aartjan Beekman. 2012. Recognition of psychopathology with religious content by clergy members: A case vignette study. Mental Health, Religion and Culture 15: 205-15. [CrossRef]

Pargament, Kenneth I., and James W. Lomax. 2013. Understanding and addressing religion among people with mental illness. World Psychiatry 12: 26-32. [CrossRef] [PubMed]

Pargament, Kenneth I., Harold G. Koenig, and Lisa M. Perez. 2000. The many methods of religious coping: Development and initial validation of the RCOPE. Journal of Clinical Psychology 56: 519-43. [CrossRef] 
Park, Crystal L. 2013. Religion and meaning. In Handbook of the Psychology of Religion and Spirituality, 2 nd ed. Edited by Raymond R. Paloutzian and Crystal L. Park. New York: Guilford Press, pp. 357-99.

Park, Crystal L., Donald Edmondson, and Amy Hale-Smith. 2013. Why religion?: Meaning as motivation. In APA Handbook of Psychology, Religion, and Spirituality: Context, Theory, and Research. Edited by Kenneth I. Pargament, Julie J. Exline and James W. Jones. Washington, DC: American Psychological Association, pp. 157-71.

Patterson, Debra. 2010. The linkage between secondary victimization by law enforcement and rape case outcomes. Journal of Interpersonal Violence 26: 328-47. [CrossRef] [PubMed]

Ray, Tomas. 2013. Regnbågsmässa: Kyrkans botgudstjänst [Rainbow mass: The Church's service for atonement]. In Från Ökenmässa till hårdrock halleluja: Specialgudstjänster i Borgå stift. [From Desert Mass to Hardrock Halleluja: Themed Church Services in the Diocese of Borgå]. Edited by Fredrik Portin. Helsinki: Fontana Media, pp. 93-105.

Redmond, Sheila A. 1989. Christian "virtues" and recovery from child sexual abuse. In Christianity, Patriarchy and Abuse: A Feminist Critique. Edited by Joanne Carlson Browne and Carole R. Bohn. New York: Pilgrim Press, pp. 70-88.

Romans, Sarah E., J. L. Martin, J. C. Anderson, M. L. O'Shea, and P. E. Mullen. 1995. Factors that mediate between child sexual abuse and adult psychological outcome. Psychological Medicine 25: 127-42. [CrossRef] [PubMed]

Rudolfsson, Lisa, and Inga Tidefors. 2009. Shepherd My Sheep: Clerical readiness to meet psychological and existential needs from victims of sexual abuse. Pastoral Psychology 58: 79-92. [CrossRef]

Rudolfsson, Lisa, and Inga Tidefors. 2013. I stay and I follow: Clerical reflections on pastoral care for victims of sexual abuse. Journal of Pastoral Care and Counseling 67: 1-14. [CrossRef]

Rudolfsson, Lisa, and Inga Tidefors. 2014. I have cried to Him a thousand times, but it makes no difference: Sexual abuse, faith, and images of God. Mental Health, Religion E Culture 17: 910-22. [CrossRef]

Rudolfsson, Lisa, and Inga Tidefors. 2015. The struggles of victims of sexual abuse who seek pastoral care. Pastoral Psychology 64: 453-67. [CrossRef]

Rudolfsson, Lisa, Inga Tidefors, and Leif A. Strömwall. 2012. Sexual abuse and the Christian congregation: The role of gender in pastoral care for victims. Pastoral Psychology 61: 375-88. [CrossRef]

Rudolfsson, Lisa. 2015. Walk with me: Pastoral care for victims of sexual abuse viewed through existential psychology. Ph.D. dissertation, University of Gothenburg, Gothenburg, Sweden, February 6. Available online: https: / gupea.ub.gu.se/handle/2077/37671 (accessed on 8 November 2018).

Smith, Stacy. 2004. Exploring the interaction of trauma and spirituality. Traumatology 10: 231-43. [CrossRef]

Stiftelsen Kirkelig Resurssenter a. n.d. Om Stiftelsen Kirkelig Resurssenter [About the Church Resource Center Foundation against Violence and Sexual Abuse]. Available online: http:/ / www.kirkeligressurssenter.no/ om-kirkelig-ressurssenter.html (accessed on 8 November 2018).

Stiftelsen Kirkelig Resurssenter b. n.d. Langtidsplan 2017-2020 [Long-Term Plan 2017-2020]. Available online: http:/ / www.kirkeligressurssenter.no/uploads/4/0/7/2/40726611/langtidsplan_2017-2020_endelig_ i_design.pdf (accessed on 8 November 2018).

Stiftelsen Kirkelig Resurssenter c. [The Church Resource Center Foundation against Violence and Sexual Abuse]. n.d. En verdighetshandling [An Act of Dignity]. Available online: http:/ /www.kirkeligressurssenter.no/uploads / 4/0/7/2/40726611/en_verdighetshandling_grenser_som_skaper.pdf (accessed on 8 November 2018).

Stiftelsen Kirkelig Resurssenter d. [The Church Resource Center Foundation against Violence and Sexual Abuse]. n.d. Agende [Agenda]. Available online: http:/ /www.kirkeligressurssenter.no/uploads/4/0/7/2/ 40726611/20110828_agende.pdf (accessed on 8 November 2018).

Terry, Karen J. 2015. Child sexual abuse within the Catholic Church: A review of global perspectives. International Journal of Comparative and Applied Criminal Justice 39: 139-54. [CrossRef]

The Church of Norway. 2011. The Order of the Principal Service. Available online: https:/ /kirken.no/globalassets / kirken.no/om-troen/liturgier-oversatt/the-order-of-the-principal-service.pdf (accessed on 14 November 2018).

Wilson, Laura C., and Katherine E. Miller. 2016. Meta-analysis of the prevalence of unacknowledged rape. Trauma, Violence and Abuse 17: 149-59. [CrossRef] [PubMed]

Zahnd, Brian. 2010. Unconditional? The Call of Jesus to Radical Forgiveness. Lake Mary: Charisma House.

(C) 2018 by the authors. Licensee MDPI, Basel, Switzerland. This article is an open access article distributed under the terms and conditions of the Creative Commons Attribution (CC BY) license (http:/ / creativecommons.org/licenses/by/4.0/). 